\title{
Agreement and concordance between married couples regarding family planning utilization and fertility intention in Dukem, Ethiopia
}

\author{
Chala W Diro $^{1 *}$ and Mesganaw F Afework ${ }^{2}$
}

\begin{abstract}
Background: Traditionally, women have been the main respondents for most of knowledge, attitude and practice survey related to family planning and fertility intention. However it is not well known how responses of women about husbands reflect the husband's attitude and practices. Thus this study is conducted to examine agreement of wife and husband regarding family planning use and fertility desire in Dukem, Ethiopia.

Methods: A community based cross sectional survey was conducted on 422 married couple's in Dukem town, central Ethiopia which were selected by using systematic sampling method. The study was conducted from November, 2010 to December, 2010. Data pertaining to fertility intentions and contraception was collected and the level of agreement (kappa statistics) between husbands and wives was computed.

Result: The observed concordance was $71.6 \%$ for ideal family size, $94.9 \%$ for contraceptive attitude, $95.9 \%$ for fertility desire, and $99.7 \%$ for report of number of currently living children. The unadjusted kappa statistic varied from $0.61(p<=0.000)$ for contraceptive attitude to high of $0.99(P<=0.000)$ for number of living children, for ideal family size $0.63(P<=0.000)$, fertility desire $0.91(P<=0.000)$, ever use of contraceptive $0.84(P<=0.000)$ and current use of contraceptive $0.87(\mathrm{P}<=0.000)$ having kappa values in between. Overall greater degree of agreement was observed for reproductive health events as compared to family planning attitudes and intentions.

Conclusion: In surveys pertaining to reproductive health events, the wife's response may be taken as proxy for the couple's response, but for assessing family planning attitudes and intentions, may require collecting information from husbands and wives separately.
\end{abstract}

\section{Background}

Traditionally, women have been respondent for the most of knowledge, attitude and practice survey related to family planning and fertility intentions [1].

However, it has been now realized that programs that exclusively focus on either men or women may fail because most sexual, family planning, and child bearing decision are made or may potentially be able to be made by both partners together and the response by one of them may not reflect the reality $[1,2]$.

Moreover, available studies show that in many developing countries male often dominate when any important

\footnotetext{
* Correspondence: chaliyo22@gmail.com

'Department of Public Health, Faculty of Health Sciences, Wolaita Sodo University, Wolaita Sodo, Ethiopia

Full list of author information is available at the end of the article
}

decision are taken in the family, such as reproduction, family size, and contraceptive use [3,5-8].

Furthermore, the level of spousal agreement regarding fertility and family planning remains an important area for utilization of reproductive service. Although high concurrence would be expected because of daily partner contact and common living conditions, cross national studies of couple concurrence on contraceptive methods use show frequent discrepancies between husbands and wives reports [4,9-12].

Thus this study examines agreement between wife and husband on family planning use and fertility intention in Dukem central Ethiopia. 


\section{Methods}

\section{Design and study area}

Community based Cross-sectional study was conducted in Dukem town, central Ethiopia from November, 2010 to December, 2010. Dukem town is $37 \mathrm{~km}$ away to south east of the capital of Addis Ababa and is divided into four kebeles $^{1}$ The town's total population is 44,009 of which $24,313(55 \%)$ are males and 19,696(45\%) are females.

\section{Study population and sampling procedure}

The study population comprises married couples aged 15-49 residing in Dukem town that was selected by using systematic random sampling techniques.

Sample size was calculated using single proportion formula as follows;

$$
\mathrm{n}=(\mathrm{Z} \mathbf{\alpha} / \mathbf{2}) \mathbf{2} \mathbf{p}(\mathbf{1}-\mathbf{p})
$$

Where

$\mathbf{n}=$ the desired sample size.

$\mathbf{p}=$ proportion of agreement of couples in sub-Saharan countries on contraceptive use $47 \%-82 \%$ take the minimum proportion [13].

$\mathrm{Z} \alpha / 2=$ critical value at $95 \%$ confidence level of certainty (1.96).

$\mathbf{d}=$ the margin error between the sample and the population $=5 \%$. using the above formula sample size for single population proportion the desired sample size is 383.considering non response rate of $10 \%$ the total sample size used for the study was 422 married couples.

As shown in (Figure 1) the sample was determined proportional to the size of the total house hold population of each kebele. Systematic sampling method was used to select the households from each kebele, where the sampling interval were the total number of households in each kebele divided by the corresponding number of households to be interviewed in each kebele.

The first household interviewed was determined from the kebele house number register using lottery method. The next household was identified by systematically adding the number of interval to the preceding one. If more than one eligible respondent were found in the selected household, only one respondent was chosen by lottery method. In cases where no eligible is identified in the selected household, the interviewer was moving to the next household.

Data were collected using pretested structured questionnaire, which was administered by the trained data collectors. The interviews were conducted at the respondent's home and both husband and wives were interviewed on the same day but separately (Figure 1).

\section{Data analysis}

Data were entered into Epi info 3.5.1 and analyzed using SPSS 16 soft ware package. First frequencies of the overall distribution of the variables under study were done.

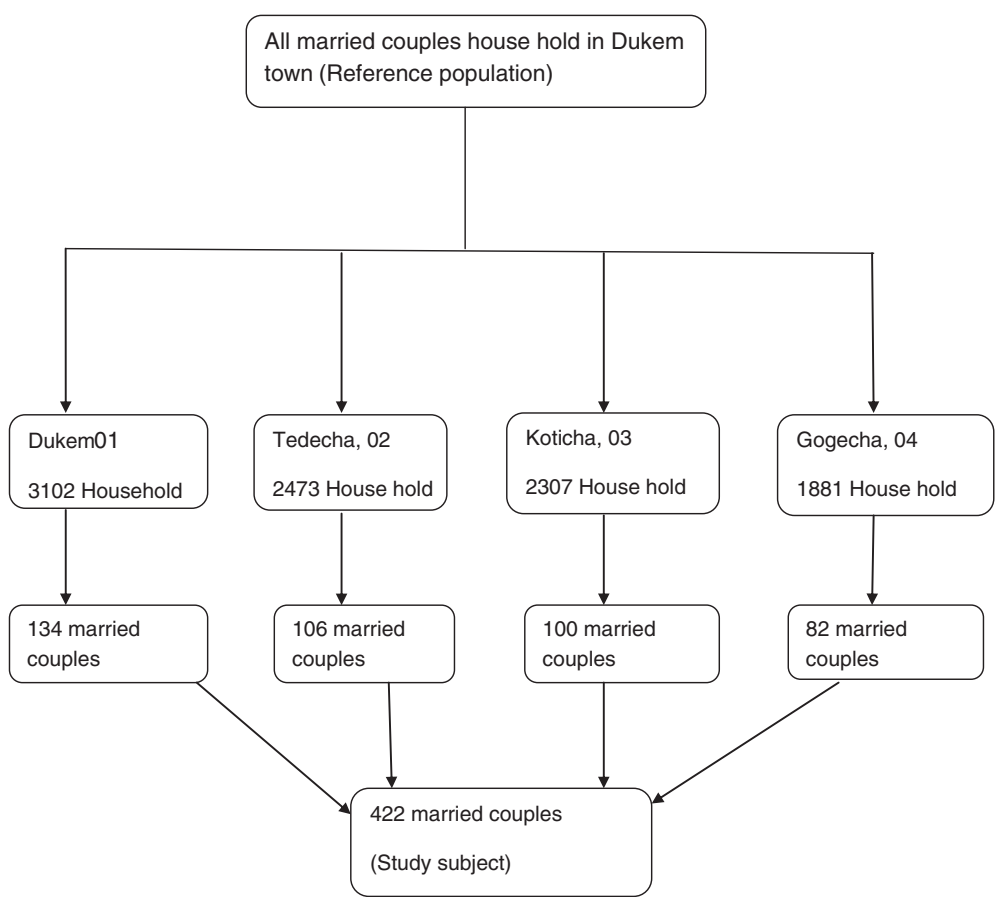

Figure 1 Schematic representation of sampling procedure. 
Kappa statistics was done to see the level of agreement of couples on family planning utilization and fertility desire.

As observed by others finding an adequate measure for distinguishing between spousal concordance that occurs by chance and actual agreement are methodological difficulty. In addition the Kappa statistics is influenced by the distributions of data across the categories that are used. As Kappa statistics may be influenced by the presence of more than two categories and by high prevalence of the outcome under consideration, we used weighted kappa and prevalence adjusted kappa wherever appropriate $[14,15]$.

\section{Ethical consideration}

Ethical clearance was obtained from the school of public health, and Addis Ababa University College of health science ethical committee. A formal letter was also submitted to all the concerned bodies to obtain their cooperation. Verbal informed consent was obtained from all study participants after explaining the purpose of the study. The participation was voluntarily and they could withdraw from the study at any time without explanation. Confidentiality was assured and no personality identifying details were recorded.

\section{Result}

\section{Socio demographic characteristics}

A total of 422 couples were interviewed. The age range for wives was from 16 to 46 years with mean age of 27.9 and for husband was from 20 to 53 years with mean age of 32.8 years. As indicated in Table 1, majority of men, $383(90.8 \%)$ and the women 326(77.2\%) reported attending formal education. Most of those who reported attending formal education, 321(76.1\%) of men and 297 (70.3\%) of women attended elementary and high school [grade 10 and below]. About 21\% of women and $9 \%$ of men were illiterate.

\section{Reproductive history}

More than half $53.1 \%$ of women were married at ages less than 19 years, while only $11.8 \%$ men did so. The minimum age at marriage reported for women was 13 years and for men was 15 years. The mean age at marriage was 19.7 and 24.6, and standard deviation $3.9 \& 4.7$ for women \& men respectively.

$386(91.5 \%)$ had ever born children and the rest did not have. As shown in Figure 2 Out of this about $56.7 \%$ had one to two children, $30.3 \%$ had three to four children, $7.8 \%$ of them had five to six children, and the rest $5.2 \%$ had more than six children ever born and the mean number of ever born children for a couple was 2.7.

Among these ever born children $58.5 \%$ one to two children, about $31.1 \%$ three-four children, 3.5\% five to six children, and $3.9 \%$ more than six children respectively
Table 1 Socio demographic characteristics of married couples in Dukem town, 2010 ( $n=422)$

\begin{tabular}{|c|c|c|c|c|c|}
\hline \multirow[b]{2}{*}{ Characteristics } & & \multicolumn{2}{|c|}{ Wife } & \multicolumn{2}{|c|}{ Husband } \\
\hline & & No & $\%$ & No & $\%$ \\
\hline \multirow[t]{5}{*}{ Religion } & Orthodox & 358 & 84.8 & 358 & 84.8 \\
\hline & Protestant & 56 & 13.3 & 54 & 12.8 \\
\hline & Muslim & 6 & 1.4 & 7 & 1.7 \\
\hline & Catholic & 2 & .5 & 3 & .7 \\
\hline & Total & 422 & 100.0 & 422 & 100.0 \\
\hline \multirow[t]{6}{*}{ Ethnicity } & Oromo & 292 & 69.2 & 289 & 68.5 \\
\hline & Amhara & 120 & 28.4 & 112 & 26.5 \\
\hline & Tigre & 2 & .5 & 8 & 1.9 \\
\hline & Gurage & 7 & 1.7 & 10 & 2.4 \\
\hline & Others & 1 & .2 & 3 & .7 \\
\hline & Total & 422 & 100.0 & 422 & 100.0 \\
\hline \multirow[t]{8}{*}{ Education } & Illiterate & 87 & 20.6 & 36 & 8.5 \\
\hline & Read \& write & 9 & 2.1 & 3 & .7 \\
\hline & Elementary & 120 & 28.4 & 78 & 18.5 \\
\hline & Junior & 130 & 30.8 & 140 & 33.2 \\
\hline & High school & 47 & 11.1 & 103 & 24.4 \\
\hline & Preparatory & 21 & 5.0 & 45 & 10.7 \\
\hline & Higher education & 8 & 1.9 & 17 & 4.0 \\
\hline & Total & 422 & 100.0 & 422 & 100.0 \\
\hline
\end{tabular}

were alive children. The mean number of alive children was 2.5 (Figure 2).

About $65.9 \%$ of the respondents wanted to have additional children and the rest did not. More than half (52.6\%) of a couple wanted to have three to four children, while about one third of couple wanted to have one to two children. The mean of ideal child desire was 3.4 children, where 1.9 was for male child and 1.5 was for female child. The minimum was 1 child and the maximum was 12 children (Figure 3 ).

\section{Agreement level between husband and wife regarding contraceptive practice, attitude and fertility desire}

Table 2 shows proportional agreement of the number of living children as reported by husbands and wives. Overall in $99.7 \%(95 \%$ CI: 99.2 to $100.2 \%$ ) of cases, both partners reported the same number of living children and the kappa statistic was $0.99(\mathrm{p}<=0.000)$, which corresponds to excellent agreement. In one case where there was a difference in reported number of children, it was husband who reported more number of children.

As indicated in Table 2, proportional agreement for ever use of contraception irrespective of the method showed 95.5\%(95\% CI: $94.5 \%$ to $96.5 \%)$ overall agreement between husbands and wives. The kappa statistic was 0.84 $(\mathrm{P}<=0.000)$, which corresponds to excellent agreement. Ever use of contraception was reported by sixteen $3.8 \%$ wives while husbands reported that they had never used 


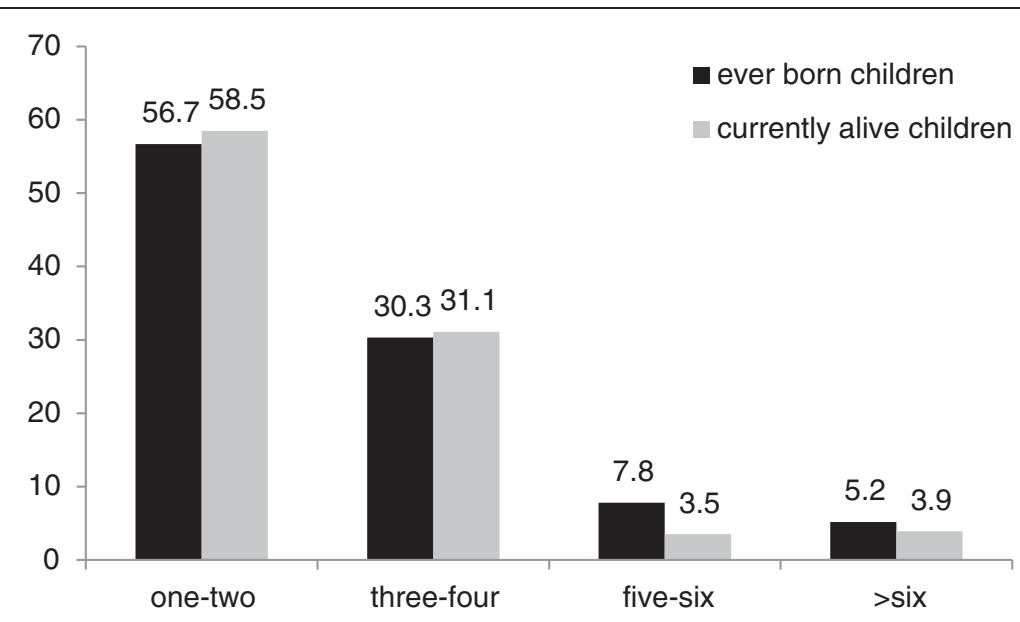

Figure 2 Number of ever born and alive children for married couples in Dukem town, 2010.

any contraception. In most of the cases, the wives had taken oral pills and it could be that they did not inform their husbands regarding this. Ever use of contraception was reported by three $0.7 \%$ husbands when wives reported otherwise. This difference may be attributable to differences of perception between spouses regarding traditional methods or may be indicative of existence of multiple sexual partners condom use.

As shown in Table 2 Current use of contraception as reported by husbands and wives showed 95.7\%(95\% CI 94.7 to $96.7 \%)$ over all agreement. The kappa statistic was $0.87(\mathrm{P}<=0.000)$, which corresponds to excellent agreement. Current use of contraception was reported by twelve $2.8 \%$ wives while the husband reported using none. Six $1.4 \%$ husbands reported current use of contraception while their wives did not. It may be inferred that there is covert contraceptive use by the couples.

Proportional agreement for fertility desire showed agreement between husband and wives is $95.9 \%(95 \%$ CI: 94.01 to $97.8 \%$ ) of cases, $31 \%$ of couples wanting no more children and $65.9 \%$ wanting more children. The kappa statistic was $0.91(\mathrm{P}<=0.000)$. The disagreement was unevenly divided across the remaining two cells, with 4 cases where the wife desired more children while the husband did not and 13 cases where the husband desired more children but wives did not.

Proportional agreement of ideal family size showed that in $71.6 \%(95 \%$ CI: 67 to $76 \%)$ of cases there was agreement between husband and wife. The kappa statistics was 0.63 (P-value 0.000$)$. In $14.5 \%$ of cases, the husband wanted more children than the wife did, while in $13.9 \%$ of cases the wife wanted more children than the husband did.

Cross tabulation of attitude towards contraception shows that there was $94.8 \%(95 \%$ CI: 92.8 to $97 \%)$ overall agreement between husbands and wives in attitude toward contraception; both partners approved of contraception in $90.3 \%$ cases. The unadjusted kappa statistic was 0.6 $(\mathrm{P}<=0.000)$ which corresponds to good agreement. In

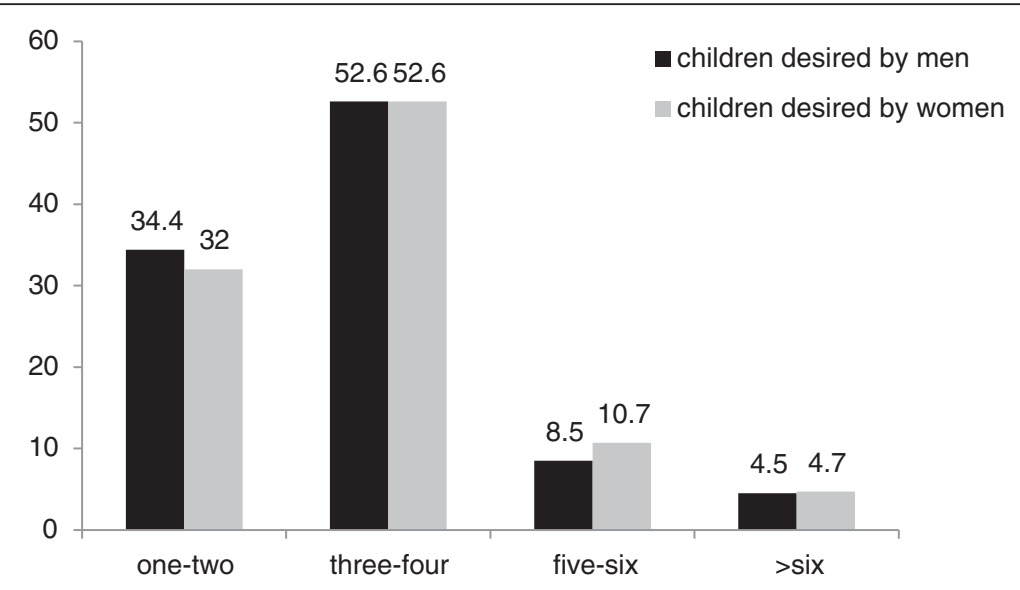

Figure 3 Number of children desired by married couples in Dukem town, 2010( $n=422)$. 
Table 2 Agreement level between husband and wife regarding contraceptive practice, attitude and fertility desire in Dukem town, 2010/11 ( $n=422)$

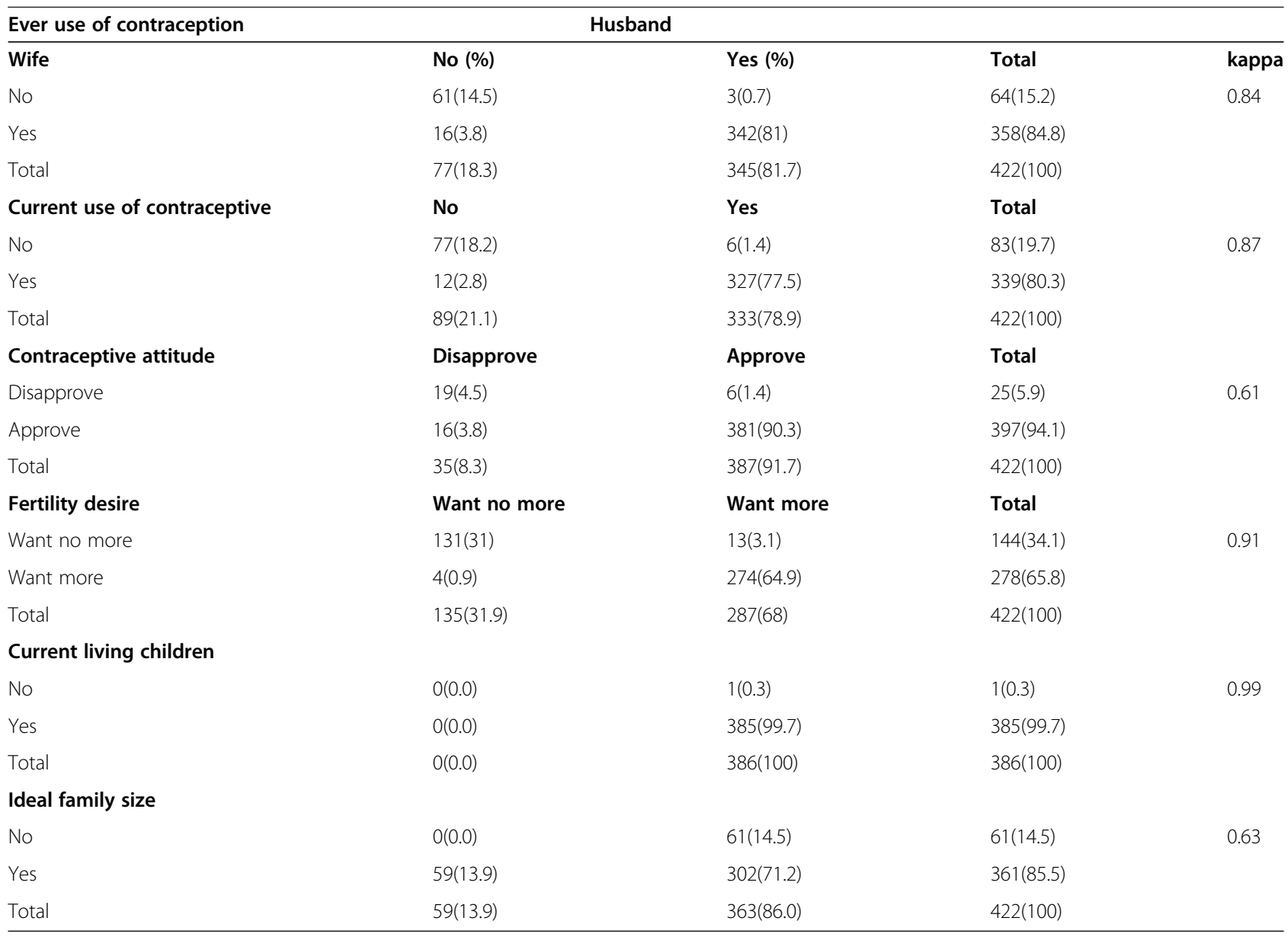

$3.8 \%$ of cases, wives approved of contraception whereas husbands did not, and in $1.4 \%$ of cases, husbands approved of contraception where as wives did not.

\section{Discussion}

This community based study used information from both husband and wife to assess the agreement between married couples regarding family planning utilization and fertility desire in Dukem town.

The age range for wives was from 16 to 46 years with mean age of 27.9 and for husband was from 20 to 53 years with mean of 32.8 years. This mean age difference is due to the fact that only women with age range of 15-49 were included in the study and also mostly women married husband elder than themselves [16-18].

The level of spousal agreement regarding fertility and family planning remains an important area for utilization of reproductive service. For this study on current reproductive attitude and behavior among the couples with both partners in their first marriage only one valid response can be recorded for a couple for objective events like number of children born and current use of contraception.
Any differences indicate response error on the part of one spouse or both. Determining which respondent give the correct response is usually impossible because validation studies of these indices are lacking. The minor differences in objective events in the present study can be explained by the male dominated culture of this study population [19-22].

In this study, the observed agreement between husbands and wives regarding reporting of reproductive health events and family planning attitudes and intentions varied from moderate $71.6 \%(95 \%$ CI:67.3 to 75.9$)$ for ideal family size to a high of $99.7 \%(95 \%$ CI:99.2 to $100.2 \%$ ) for a number of currently living children. But the unadjusted kappa statistic varied from $0.61(\mathrm{P}<=0.000)$ for contraceptive attitude to $0.997(\mathrm{P}<=0.000)$ for a number of living children.

In agreement with this study, research from Turkey reported that spousal reports on most fertility and contraceptive use measures demonstrated moderate to high concordance, where as reports of approval of family planning showed only fair concordance [4,23-26].

This study revealed that high level of agreement in reporting the number of living children between husbands 
and wives. A high level of agreement in number of living children was also reported by a study done in rural Maharashtra, India where only $0.4 \%$ disagreement was observed for number of currently living sons and daughters. They also concluded that women reported live births more accurately than men [27-29].

In this study current use of contraception as reported by husbands and wives showed 95.7\%(95\% CI 94.7 to $96.7 \%)$ over all agreement. The kappa statistic was $0.87(\mathrm{P}<=0.000)$, which corresponds to excellent agreement. In a study using data from six demographic and health surveys of sub Saharan Africa, contraceptive use agreement ranged from $47 \%$ to $82 \%$, but among couples in whom one or both reported use, the both category represented less than half in all nations except Zimbabwe [13,30].

Whereas discrepancies in the reporting of events indicate reporting errors on the part of one or both spouses, differences of attitudes and intentions are expected because these are subjective indicators.

Available studies show that in many developing countries, males often dominate in decision making in the family, including in issues related to reproduction, family size and contraceptive use. Research in Kenya suggests that contraception is 2-3 times more likely to be used when husbands, rather than wives, want to cease childbearing [31,32].

Male involvement not only helps in making a contraceptive more acceptable, but also makes its effective use and continuation more likely. On the other hand, even if the wife wants to use a contraceptive, she may not be able to use it or may be forced to discontinue the method if the husband disapproves of contraception. In study conducted in Indonesia, husband's approval was the most important determinant of contraceptive use [33].

\section{Conclusion}

Overall, a greater degree of agreement was observed for reproductive health events as compared to family planning attitudes and intentions. The latter are more subjective outcomes and can be expected to vary among spouses. Thus, we can infer that for reproductive health events, wives responses can be taken as proxy for the couple's response but family planning attitudes and intentions may require collection of information both from husbands and wives.

\section{Endnote}

${ }^{\mathrm{a}}$ Kebele is the smallest administrative unit in Ethiopia.

\section{Competing interests}

The authors declare that they have no competing interests.

\section{Authors' contributions}

CW was responsible for the development of study design, implementation, analysis, interpretation and the preparation of the draft manuscript. MF involved in the design, the writing, interpretation and critical revision of the paper for intellectual content. All authors read and approved the final manuscript.

\section{Acknowledgment}

This study was financially supported by the United Nation Population Fund. We would like to acknowledge with gratitude all the individuals who facilitated the implementation of study. We would like to extend our gratitude to all study participants for their time and willingness to take part in the study.

\section{Author details}

'Department of Public Health, Faculty of Health Sciences, Wolaita Sodo University, Wolaita Sodo, Ethiopia. ${ }^{2}$ School of Public Health, Addis Ababa University, Addis Ababa, Ethiopia.

Received: 23 April 2013 Accepted: 25 September 2013 Published: 1 October 2013

\section{References}

1. Yadav K, Singh B, Goswami K: Agreement and concordance regarding reproductive intentions and contraception between husbands and wives in rural ballabgarh, India. Indian J Community Med 2010, 35(1):19-23.

2. Yadav K, Singh B, Goswami K: Unmet family planning need: differences and levels of agreement between husband-wife, haryana. India. Indian J Community Med 2009, 34(3):188-191.

3. UNFPA: Male Involvement in Reproductive Health, Including Family planning and Sexual Health. Technical Report, Volume 28. New York: UNFPA; 1995.

4. Kulczycki A: Husband-wife agreement, power relations and contraceptive use in Turkey. International Family Planning Perspective 2008, 34(3):127-137.

5. Akinrinola B, Sasheela S: Couples Fertility and contraception Decision Making in Developing Countries: Hearing the Man's Voice. International Family Planning prespective 1998, 24(1):15-24.

6. Toure L: Male Involvement in Family Planning: a Review of Programmes and Selected Programme Initiatives in Africa. 1996. [Accessed date 5/8/11] http://pdf. usaid.gov/pdf_docs/PNABY584.pdf.

7. Tolassa Y: The role of men in family planning in a rural community of western Ethiopia. Addis Ababa University: Thesis (un published); 2004.

8. Orji EO, Ojofeitimi EO, Olanrewaju BA: The role of men in family planning decision-making in rural and urban Nigeria. Eur J Contracept Reprod Health Care 2007, 12(1):70-75.

9. Zewudu W, Sibanda A, Dennis P: The proximate determinants of the decline to below replacement fertility in Addis Ababa. Studies in FP 2003, 34(1):1-7.

10. Haregewoin C, Emebet M: Towards Gender equality in Ethiopia. Swedish International Development Cooperation Agency: A Profile of Gender Relations; 2003.

11. Assefa $H$, Betermariam B, Dennis PH: Household organization women's Autonomy, \& contraceptive Behavior in southern Ethiopia. Studies in Fp 1999, 30(34):302-314.

12. Central Statistical Authority, and ORC MACRO: Ethiopia Demographic and Health Survey 2005. Addis Ababa and Maryland: CSA and ORC Macro; 2006.

13. Becker $\mathrm{S}$, Hossain MB, Thomson E: Disagreement in spousal reports of current contraceptive use in sub-Saharan Africa. J Biosoc Sci 2006, 38(6):779-796.

14. Bankole A, Singh S: Couples fertility and contraceptive decision making in developing countries hearing men's voice. Int Fam Plan perspect 1998, 24:15-24.

15. Byrt T, Bishop J, Carlin JB: Bias, prevalence and kappa. J Clin Epidemiology 1993, 46:39-42.

16. Bongaarts J, Potter RC: Fertility, Biology and Behavior: An Analysis of the Proximate Determinants of Fertility. New York and London : New york Academic press; 1983.

17. Cleland J, Wilson C: Demand Theories of Fertility Transition: an Iconoclastic View. Popul Stud 1987, 41(4):5-30

18. Bongaarts J: Trends in unwanted childbearing in the developing world. Stud Fam Plann 1997, 28(4):267-277.

19. Pebley R, Delgado H, Brinemann E: Fertility Desires and Child Mortality among Guatemalan Women. Studies in family Planning 1989, 10(4):129-136.

20. Short ES, Kiros G: Husbands, Wives, sons and Daughters Fertility Preferences and the Demand for Contraception in Ethiopia. Popul Res Policy Rev 2002, 21:377-402. 
21. Mohammod N, Ringheim K: Knowledge, Approval and Communication about family planning as correlates of desired fertility among spouses in Pakistan. International Family Planning perspective 1997, 23(3):122-129.

22. Gupta N, Katende C, Bessinger R: Association of Mass Media Exposure with Family Planning Attitudes and Practices in Uganda. Stud Fam Plann 2003, 34(1):19-31.

23. Biruk T, Michelle JH: Covert contraceptive use and discordant fertility preferences among Ethiopian Couples. 2007. [Accessed date 7/3/11] http://paa2010.princeton.edu/papers/100743.

24. Freedman R, Blanc AK: Fertility Transition: an update. International Family Planning Perspectives 1992, 18(2):44-50. 72

25. Kirk D, Pillet P: Fertility levels, trends and differentials in sub- Saharan Africa in the 1980s and 1990s. Stud Fam Plann 1998, 29(1):1-22.

26. Antenanane K: Community Based Family Planning Services: A PerformanceAssessment of the Jimma FP CBD Projec. Ethiopian Journal of Health development 1997, 11(1):1-5.

27. Becker S, Costenbader E: Husbands' and wives' reports of contraceptive use. Stud Fam Plann 2001, 32(2):111-129.

28. David O: Communication and Decision-Making Factors Influencing Couples Interest in Family Planning and Reproductive Health Behaviours in Nigeria. Stud Tribes Tribals 2008, 6(2):99-103.

29. Vlassoff $C$, Vlassoff M: Misreporting in rural fertility data: an analysis of husband-wife disagreement. J Biosoc Sci 1978, 10(4):437-444

30. Assefa H, Tekleab M, Misganaw F: Family planning in Ethiopia. In Epidemiology and Ecology of Health and Disease in Ethiopia. Edited by Yemane B, Damen H. Kloos H. Addis Ababa: Shama Books: 2006.

31. Central Statistical Authority: The1990 National Family and Fertility Survey. Addis Ababa, Ethiopia: Central Statistical Authority; 1993.

32. Dodoo FN: Men matter: additive and interactive gendered preferences and reproductive behavior in Kenya. Demography 1998, 35(2):229-242.

33. Joesoef MR, Baughman AL, Utomo B: Husband's approval of contraceptive use in metropolitan Indonesia: program implications. Stud Fam Plann 1988, 19(3):162-168.

doi:10.1186/1471-2458-13-903

Cite this article as: Diro and Afework: Agreement and concordance between married couples regarding family planning utilization and fertility intention in Dukem, Ethiopia. BMC Public Health 2013 13:903.

\section{Submit your next manuscript to BioMed Central and take full advantage of:}

- Convenient online submission

- Thorough peer review

- No space constraints or color figure charges

- Immediate publication on acceptance

- Inclusion in PubMed, CAS, Scopus and Google Scholar

- Research which is freely available for redistribution 